\title{
Noninvasive Ventilation and Oxygen Therapy after Extubation in Patients with Acute Respiratory Failure: A Meta-analysis of Randomized Controlled Trials
}

\author{
Souvik Maitra ${ }^{1}$, Sulagna Bhattacharjee ${ }^{2}$, Anirban Som ${ }^{3}$
}

\begin{abstract}
Background: Role of noninvasive ventilation (NIV) following extubation in patients with acute respiratory failure is debatable. NIV may provide benefit in post surgical patients, but its role in nonsurgical patients is controversial.

Materials and methods: PubMed and Cochrane Central Register of Controlled Trials (CENTRAL) were searched (from 1946 to 20 th November 2017) to identify prospective randomized controlled trials, where postextubation NIV has been compared with standard oxygen therapy in adult patients with acute respiratory failure.

Results: Data of 1525 patients from 11 randomized trials have been included in this meta-analysis. Two trials used NIV to manage postextubation respiratory failure. Pooled analysis found that mortality rate at longest available follow-up [OR $(95 \% \mathrm{Cl}) 0.84(0.50,1.42) ; \mathrm{p}=0.52]$ and reintubation rate [OR $(95 \% \mathrm{Cl}) 0.75(0.51,1.09) ; \mathrm{p}=0.13]$ were similar between NIV and standard oxygen therapy. NIV did not decrease intubation rate when used as preventive modality [OR $(95 \% \mathrm{Cl}) 0.65(0.40,1.06) ; \mathrm{p}=0.08]$. Duration of ICU stay was also similar in the two groups [MD $(95 \% \mathrm{Cl}) 0.46(-0.43,1.36)$ days; $\mathrm{p}=0.3]$

Conclusion: Post extubation NIV in non- surgical patients with acute respiratory failure does not provide any benefit over conventional oxygen therapy.

Keywords: BiPAP, CPAP, Length of stay, Mortality, Noninvasive ventilation, Postextubation respiratory failure, Reintubation Indian Journal of Critical Care Medicine (2019): 10.5005/jp-journals-10071-23236
\end{abstract}

Postextubation respiratory failure is an established factor responsible for mortality in critically ill patients. ${ }^{1}$ Noninvasive positive pressure ventilation (NIV) has been used both as a therapeutic and preventive strategy for postextubation respiratory failure. An observational study has reported that use of NIV in various clinical settings including postextubation respiratory failure patients is increasing over the last 15 years. ${ }^{2} \mathrm{~A}$ large observational study in 2014 found survival benefit from NIV, in comparison to invasive mechanical ventilation when used as a first-line strategy in immunocomprmised and acute-on-chronic respiratory failure patients. ${ }^{3}$ A recent Cochrane database systematic review ${ }^{4}$ also reported benefit from NIV as first-line intervention in patients with acute hypercapnic respiratory failure secondary to an acute exacerbation of chronic obstructive pulmonary disease (COPD). As endotracheal intubation is associated with several complications such as ventilator-associated pneumonia, barotrauma and tracheooesophageal fistula; intubation and mechanical ventilation associated with complications may be reduced with the use of NIV. However, benefits of NIV in the postextubation respiratory failure is less clear. A meta-analysis of 1382 patients published in 2014 found that neither early application of NIV following extubation preemptively nor after established respiratory failure following extubation associated with a benefit in terms of mortality or reintubation. ${ }^{5} \mathrm{~A}$ recent randomized controlled trial reported that post extubation NIV use in COPD patients is associated with a less incidence of respiratory failure but an increased duration of intensive care unit (ICU) stay. ${ }^{6}$ However, no benefit was reported in terms of reintubation rate or mortality. We designed this metaanalysis and systematic review to know the clinical utility of NIV in prevention and management of postextubation respiratory failure.
${ }^{1}$ Department of Anesthesiology, Pain Medicine and Critical Care, All India Institute of Medical Sciences, New Delhi, India

${ }^{2}$ Departmentof Anesthesiology, All India Institute of Medical Sciences, New Delhi, India

${ }^{3}$ Department of Anesthetics, Bradford Teaching Hospital, Bradfordshire, United Kingdom

Corresponding Author: Souvik Maitra, Department of Anesthesiology, Pain Medicine and Critical Care, All India Institute of Medical Sciences, New Delhi, India, phone: 8146727891, e-mail: souvikmaitra@live.com

How to cite this article: Maitra S, Bhattacharjee S, Som A. Noninvasive Ventilation and Oxygen Therapy after Extubation in Patients with Acute Respiratory Failure: A Meta-analysis of Randomized Controlled Trials. Indian J Crit Care Med 2019;23(9):414-422.

Source of support: Nil

Conflict of interest: None

\section{Materials and Methods}

We have followed the recommendations of Preferred Reporting ltems for Systematic Reviews and Meta-Analyses (PRISMA) statement for conducting and reporting results of this meta- analysis. ${ }^{7}$

\section{Eligibility Criteria}

Prospective randomized controlled trials comparing any modality of NIV such as bi level positive airway pressure (BiPAP) or continuous positive airway pressure (CPAP) or non-invasive pressure support ventilation (NIV-PSV) with a standard oxygen therapy protocol in the prevention or management of post-extubation respiratory failure in adult patients has been included in this meta-analysis.

(c) The Author(s). 2019Open Access This article is distributed under the terms of the Creative Commons Attribution 4.0 International License (https://creativecommons. org/licenses/by-nc/4.0/), which permits unrestricted use, distribution, and non-commercial reproduction in any medium, provided you give appropriate credit to the original author(s) and the source, provide a link to the Creative Commons license, and indicate if changes were made. The Creative Commons Public Domain Dedication waiver (http://creativecommons.org/publicdomain/zero/1.0/) applies to the data made available in this article, unless otherwise stated. 
Studies where NIV has been compared with invasive ventilation as a weaning modality or where it has been compared with high flow oxygen therapy has not been included in this meta-analysis. We included RCTs where mortality data at least in one time point or reintubation rate were reported.

\section{Information Sources}

PubMed and CENTRAL (Cochrane Central Register of Controlled Trials) were searched for potentially eligible trials from inception to 20th November 2017. We did not impose any language restriction or date restriction in search strategy. References of the previously published meta-analyses were also searched manually to identify eligible trials.

\section{Search Strategy}

Following keywords were used to search database: "acute hypoxemic respiratory failure, acute respiratory failure, noninvasive ventilation, BiPAP, CPAP, NIV, post extubation respiratory failure". Details of PubMed search strategy have been provided in online supplementary material.

\section{Study Selection}

Two authors (SM and SB) independently searched title and abstract of the potentially eligible articles. Finally, full text of the possible articles was retrieved and assessed for eligibility. Any disputes between the two authors were solved by discussion.

\section{Data Collection Process}

Two authors (SM \& SB) independently extracted required data from the eligible RCTs and all data were initially tabulated in a Microsoft Excel $^{\mathrm{TM}}$ (Microsoft Corp., Redmond, WA) data sheet.

\section{Data Items}

Following data were retrieved from the full text for all studies: First author, year of publication, country where work was done, sample size, characteristics of included patients, respiratory goals (oxyhemoglobin saturation, arterial oxygen and $\mathrm{PaO}_{2} / \mathrm{FiO}_{2}$ ), details of noninvasive ventilation (type of NIV, timing of NIV and duration, details of rescue therapy), details of oxygen therapy, clinical outcome (reported complications, organ dysfunction, length of hospital and ICU stay, and mortality at different time points).

\section{Risk of Bias in Individual Studies}

Two authors (SM and AS) independently assessed the methodological quality of the included studies. Following methodological questions were searched from the studies as per the Cochrane methodology: method of randomization, allocation concealment, blinding of the participants and personnel, blinding of outcome assessment, incomplete data reporting, selective reporting and any other bias. For each area of bias, we will designate the trials as low risk of bias, unclear risk of bias or high risk of bias. Risk of bias at individual study level will be graphically presented in the review.

\section{Summary Measures and Synthesis of Results}

Primary outcome of this meta-analysis is 'mortality at longest available follow-up' in the included patients. Secondary outcomes are reintubation rate and length of hospital and ICU stay.

For continuous variables such as length of ICU stay and hospital stay, mean and standard deviation (SD) values were extracted for both group of patients, a mean difference was computed at the study level, and a weighted mean difference was computed in order to pool the results across all studies. If the values were reported as median and an interquartile range or total range of values, the mean value was estimated using the median and the low and high end of the range for samples smaller than 25; for samples greater than 25 , the median itself was used. The standard deviation (SD) was estimated from the median and the low and high end of the range for samples smaller than 15 , as range/4 for samples from 15 to 70 , and as range/ 6 for samples more than 70 . If only an interquartile range was available, SD was estimated as interquartile range/1.35. ${ }^{8}$

For binary outcomes, we calculated the odds ratio (OR) for each trial and the pooled OR using the inverse variance method. All statistical variables were calculated with $95 \%$ confidence interval $(95 \% \mathrm{Cl})$. The $\mathrm{Q}$ test was used to analyze heterogeneity of trials. Considering possible clinical heterogeneity due to study design and patients' population, we used a random effect model for all pooled analysis. RevMan software (Review Manager (RevMan) [Computer program]. Version 5.3. Copenhagen: The Nordic Cochrane Centre, The Cochrane Collaboration, 2014) was used for statistical analysis. Publication bias was assessed by visual inspection of funnel plot. A meta-regression analysis was planned to assess the effects of sample size, baseline risk of events in control group patients and year of publication on postoperative outcome. Metareg command in STATA version 13.0 (STATA SE 13.0, Stata Corp, College Station, TX, USA) was used for meta- regression analysis. We used GRADEpro software (GRADEpro Guideline Development Tool, McMaster University, 2015) to assess the quality of evidence and strength of recommendations as per GRADE methodology.

\section{Results}

Database searching and searching of references of previous metaanalyses revealed 9060 articles and total 160 articles were screened from abstract and title to identify potentially eligible trials. A flow diagram as per PRISMA methodology showing stages of database searching and study selection has been provided in Figure 1. Finally, data of 1525 patients from 11 randomized controlled trials have been included in this meta-analysis. ${ }^{6,9-18}$ Two trials $(n=302)$ used NIV to manage postextubation respiratory failure ${ }^{10,11}$ and in rest of the trials NIV was used immediately after extubation. Three trials $s^{6,14,15}$ recruited patients with COPD or chronic respiratory disorders only and another two trials ${ }^{12,13}$ recruited patients who are at risk of postextubation respiratory failure. Possible risk of biases as per Cochrane methodology in the individual studies has been provided in Figure 2. A summary of the study characteristics has been provided in Table 1. Quality of evidences in this review was low to moderate (Tables 2 and 3).

\section{Mortality}

Postextubation NIV does not decrease mortality at the longest available follow-up [OR $(95 \% \mathrm{Cl}) 0.84(0.50,1.42) ; p=0.52, I^{2}=56 \%$; $n=1393]$. Sub group analysis found that neither prophylactic nor therapeutic use of NIV is associated with a mortality benefit [OR $\left(95 \%\right.$ Cl) $0.68(0.36,1.23) ; p=0.21, l^{2}=48 \% ; n=1091$ and OR $(95 \%$ CI) $1.52(0.78,2.97) ; p=0.22, I^{2}=27 \% ; n=302$ respectively; Fig. 3 ].

Postextubation NIV in patients with COPD or chronic respiratory diseases significantly decreases mortality [OR $(95 \% \mathrm{Cl}) 0.42(0.20$, 0.88 ); $p=0.02, I^{2}=8 \% ; n=249$; respectively (Fig. 4). Begg's test did 


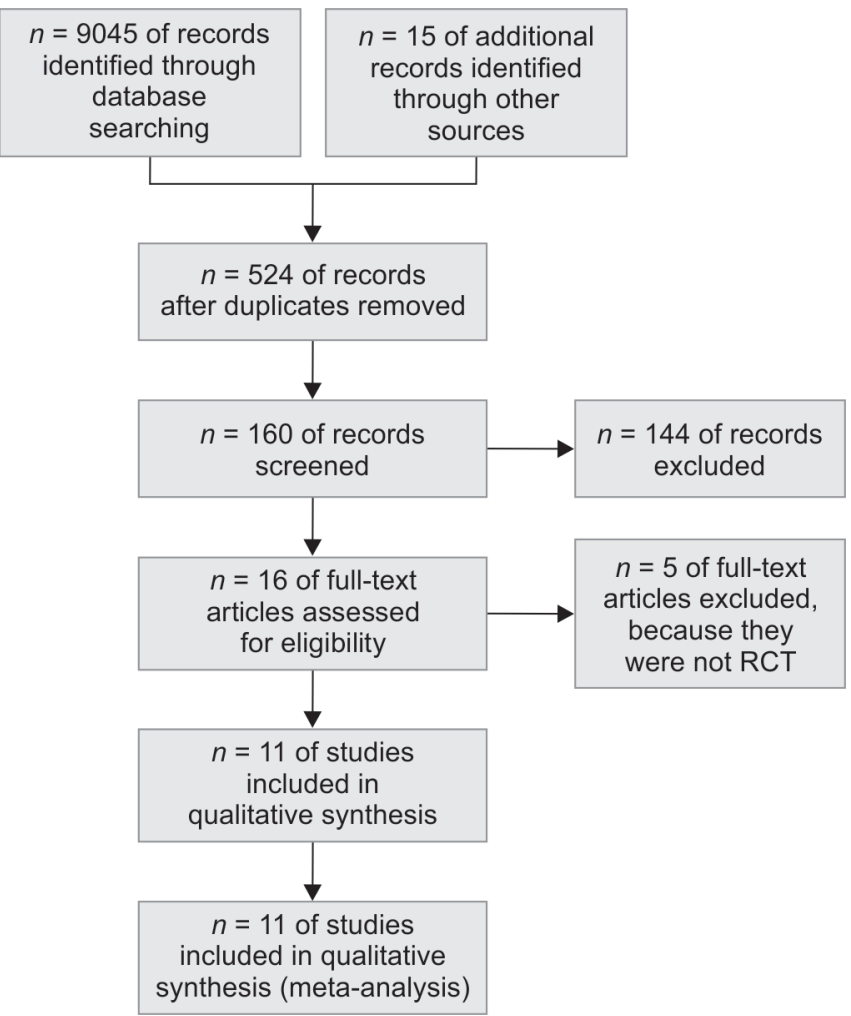

Fig. 1: Stages of database searching and study selection

not reveal any publication bias and a funnel plot for assessment of publication bias has been provided in (Fig. 5).

\section{Reintubation}

Rate of reintubation is also not decreased with the use of NIV [OR (95\% Cl) $\left.0.75(0.51,1.09) ; p=0.13, l^{2}=44 \%, n=1525\right]$. Subgroup analysis found that neither prophylactic nor therapeutic use of NIV is associated with a benefit in terms of reintubation [OR $(95 \%$ Cl) $0.65(0.40,1.06) ; p=0.08, I^{2}=51 \% ; n=1223$ and OR $(95 \% \mathrm{Cl}) 1.05$ $(0.66,1.67) ; p=0.84, l^{2}=0 \% ; n=302$ respectively; Fig. 6]. However, post-extubation NIV in patients with COPD or chronic respiratory diseases, significantly decreases rate of reintubation [OR $(95 \%$ Cl) $\left.\left.0.48(0.24,0.94) ; p=0.03, l^{2}=0 \% ; n=289\right)\right]$. No evidence of publication bias was found in Begg's test.

A meta-regression analysis found that sample size of the studies $\left(I^{2}=11.7 \%\right.$, adjusted $\left.\mathrm{R}^{2}=100 \%, p=0.28\right)$, year of publication $\left(I^{2}=\right.$ $5.8 \%$, adjusted $R^{2}=-174.7 \%, p=0.18$ ) and baseline risk of intubation in the standard therapy group patients $\left(I^{2}=19.8 \%\right.$, adjusted $R^{2}=$ $10.6 \%, p=0.22$; considering only studies where 'prophylactic' NIV was used) did not affect the rate of reintubation.

\section{Length of Stay}

Use of NIV after extubation does not decrease length of ICU stay [MD $(95 \% \mathrm{Cl}) 0.46(-0.43,1.36)$ days; $\left.p=0.31, I^{2}=0 \% ; n=890\right]$. Subgroup analysis found that neither prophylactic nor therapeutic use of NIV is associated with a benefit in terms of length of ICU stay [MD (95\% Cl) $0.56(-0.38,1.49)$ days; $p=0.25, l^{2}=0 \% ; n=588$ and MD $(95 \%$ Cl) $-0.60(-3.69,2.50)$ days; $p=0.70, I^{2}=0 \% ; n=302$, respectively; Fig. 7]. Only four studies reported length of hospital stay and it was

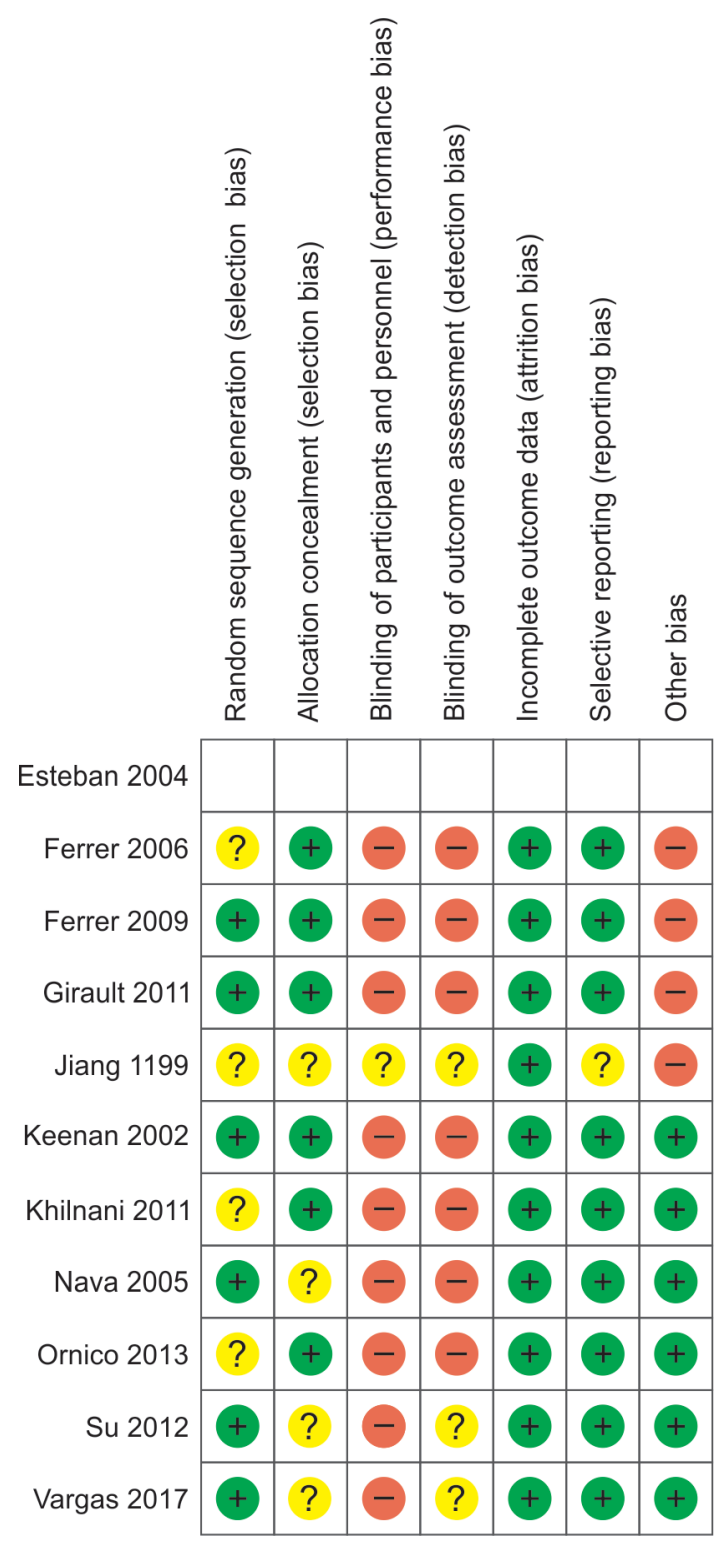

Fig. 2: Risk of biases as per Cochrane methodology in the individual studies

similar in two groups [SMD $(95 \% \mathrm{CI}) 0.07(-0.13,0.27) ; p=0.99, I^{2}=$ $0 \% ; n=389$ ]. In patients with COPD, neither length of ICU stays nor hospital stay is decreased with the use of NIV.

\section{Discussion}

Principal finding of this meta-analysis is that postextubation NIV does not provide any benefit in terms of reintubation rate, mortality and length of stay when used either as either a prophylactic or therapeutic strategy. However, in patients with chronic respiratory diseases, rate of reintubation and mortality are decreased with the use of NIV.

Extubation failure and reintubation after planned weaning in the ICU is a common problem. A prospective observational study ${ }^{19}$ found that extubation failure rate was $29 \%$ and reintubation 
Table 1: Characteristics of the included studies

\begin{tabular}{|c|c|c|c|c|}
\hline Author & Patients & Intervention & NIV duration & Standard therapy \\
\hline Jiang 1999 & $\begin{array}{l}\text { After extubation of the } \\
\text { patients who required } \mathrm{MV}\end{array}$ & $\begin{array}{l}\text { BiPAP (initial IPAP } 12 \mathrm{~cm} \\
\mathrm{H}_{2} \mathrm{O} \text { and EPAP } 5 \mathrm{~cm} \mathrm{H}_{2} \mathrm{O} \text { ) }\end{array}$ & $\begin{array}{l}72 \text { hours with temporary } \\
\text { interruption up to } 2 \text { hours }\end{array}$ & $\begin{array}{l}\text { Oxygen therapy by face } \\
\text { mask or nasal cannula at } \\
2-15 \mathrm{l} / \mathrm{m}\end{array}$ \\
\hline Keenan 2002 & $\begin{array}{l}\text { Postextubation } \\
\text { respiratory distress }\end{array}$ & $\begin{array}{l}\text { BiPAP (initial IPAP } 9 \mathrm{~cm} \\
\mathrm{H}_{2} \mathrm{O} \text { and EPAP } 4 \mathrm{~cm} \mathrm{H}_{2} \mathrm{O} \text { ) }\end{array}$ & $\begin{array}{l}\text { Continuously for } 12 \text { hours } \\
\text { followed by unassisted } \\
\text { breathing for increasing } \\
\text { duration }\end{array}$ & Supplemental oxygen \\
\hline Esteban 2004 & $\begin{array}{l}\text { Postextubation } \\
\text { respiratory failure }\end{array}$ & $\begin{array}{l}\text { NIV-PSV to achieve a Vt } \\
>5 \mathrm{~mL} / \mathrm{kg} \text { of body weight } \\
\text { and a } \mathrm{RR}<25 \text { breaths/ } \\
\text { minute }\end{array}$ & $\begin{array}{l}4 \text { hours continuously and } \\
\text { discontinuation by attend- } \\
\text { ing physician }\end{array}$ & Supplemental oxygen \\
\hline Nava 2005 & $\begin{array}{l}\text { Patients who are at risk of } \\
\text { extubation failure }\end{array}$ & $\begin{array}{l}\text { NIV pressure support with } \\
\text { PEEP }\end{array}$ & $\begin{array}{l}\text { NIV was withdrawn after } \\
48 \text { hours in patients were } \\
\text { clinically stable }\end{array}$ & $\begin{array}{l}\text { Supplemental oxygen to } \\
\text { maintain } \mathrm{SaO}_{2}>92 \%\end{array}$ \\
\hline Ferrer 2006 & $\begin{array}{l}\text { Patients who are at risk of } \\
\text { extubation failure }\end{array}$ & $\begin{array}{l}\text { BiPAP (mean IPAP } 14 \mathrm{~cm} \\
\mathrm{H}_{2} \mathrm{O} \text { and EPAP } 5 \mathrm{~cm} \mathrm{H}_{2} \mathrm{O} \text { ) }\end{array}$ & $\begin{array}{l}\text { Continuously for } 24 \text { hours } \\
\text { followed by oxygen therapy }\end{array}$ & Oxygen by Venturi mask \\
\hline Ferrer 2009 & $\begin{array}{l}\text { Patients with chronic } \\
\text { respiratory disorder with } \\
\text { hypercapnia during SBT }\end{array}$ & $\begin{array}{l}\text { BiPAP (IPAP } 12-20 \mathrm{~cm} \mathrm{H}_{2} \mathrm{O} \\
\text { and EPAP } 5-6 \mathrm{~cm} \mathrm{H}_{2} \mathrm{O} \text { ) }\end{array}$ & $\begin{array}{l}\text { Continuously for } 24 \text { hours } \\
\text { followed by oxygen therapy }\end{array}$ & Oxygen by Venturi mask \\
\hline Girault 2011 & $\begin{array}{l}\text { After extubation of the } \\
\text { patients with acute res- } \\
\text { piratory failure }\end{array}$ & NIV-PSV or BiPAP & $\begin{array}{l}\text { NIV was discontinued } \\
\text { when, required }<6 \text { hours/ } \\
\text { day or respiratory stability } \\
\text { with standard oxygen ther- } \\
\text { apy for at least } 12 \text { hours }\end{array}$ & $\begin{array}{l}\text { Standard oxygen } \\
\text { therapy to maintain } \mathrm{SaO}_{2} \\
\geq 90 \%\end{array}$ \\
\hline Khilnani 2011 & $\begin{array}{l}\text { After extubation of the } \\
\text { patients with acute exac- } \\
\text { erbation of COPD }\end{array}$ & $\begin{array}{l}\text { BiPAP (initial IPAP } 8 \mathrm{~cm} \\
\mathrm{H}_{2} \mathrm{O} \text { and EPAP } 4 \mathrm{~cm} \mathrm{H}_{2} \mathrm{O} \text { ) }\end{array}$ & 7 hours per day & $\begin{array}{l}\text { Oxygen by nasal prongs } \\
\text { or mask }\end{array}$ \\
\hline Su 2012 & $\begin{array}{l}\text { After extubation of the } \\
\text { patients who required } \\
\text { mechanical ventilation for } \\
>48 \text { hours }\end{array}$ & $\begin{array}{l}\text { BiPAP (initial IPAP 10-12 } \\
\mathrm{Cm} \mathrm{H}_{2} \mathrm{O} \text { and EPAP } 5 \mathrm{~cm} \\
\mathrm{H}_{2} \mathrm{O} \text { ) }\end{array}$ & $\begin{array}{l}\text { Patients were allowed to } \\
\text { have unassisted breathing } \\
\text { intermittently at increasing } \\
\text { intervals after } 12 \mathrm{~h} \text { of NIV }\end{array}$ & $\begin{array}{l}\text { Supplemental oxygen by } \\
\text { mask to maintain } \mathrm{SpO}_{2} \\
\geq 92 \%\end{array}$ \\
\hline Ornico 2013 & $\begin{array}{l}\text { After extubation of the } \\
\text { patients with acute res- } \\
\text { piratory failure }\end{array}$ & $\begin{array}{l}\text { BiPAP (initial IPAP } 8 \mathrm{~cm} \\
\mathrm{H}_{2} \mathrm{O} \text { and EPAP } 4 \mathrm{~cm} \mathrm{H}_{2} \mathrm{O} \text { ) }\end{array}$ & Continuously for 24 hours & $\begin{array}{l}\text { Supplemental oxygen by } \\
\text { face mask at } 5 \mathrm{l} / \mathrm{min}\end{array}$ \\
\hline Vargas 2017 & $\begin{array}{l}\text { After extubation of the } \\
\text { patients with chronic } \\
\text { respiratory diseases }\end{array}$ & $\begin{array}{l}\text { NIV pressure support } \\
\text { (initial PEEP } 4 \mathrm{~cm} \mathrm{H}_{2} \mathrm{O} \text { ) }\end{array}$ & $\begin{array}{l}\text { NIV was used for } 1 \text { hour } \\
\text { every } 3 \text { hours and at least } \\
6 \text { hours/day }\end{array}$ & $\begin{array}{l}\text { Standard oxygen } \\
\text { therapy targeting } \mathrm{SaO}_{2} \\
\geq 90 \%\end{array}$ \\
\hline
\end{tabular}

NIV, Noninvasive ventilation; MV, mechanical ventilation; BiPAP, Bi-level positive airway pressure; NIV-PSV, Noninvasive pressure support ventilation; $\mathrm{Vt}$, tidal volume; RR, Respiratory rate; COPD, chronic obstructive pulmonary disease; $\mathrm{SBT}$, spontaneous breathing trial

within 48-hour of extubation was $16 \%$ and it was independently associated with mortality with an odds of more than 5 . Despite of being increasingly used in postextubation period both as preventive or therapeutic strategy, evidence in support of NIV in these setting is limited. Most of the randomized controlled trials conducted in this setting are of small sample size, limiting their generalizability. Benefits of 'prophylactic' use of NIV in the postextubation period to prevent respiratory failure may be limited only to the patients who are at high risk of reintubation ${ }^{18}$ or in the postoperative patients. ${ }^{20}$ Glossop et al in a meta-analysis found that NIV decreases reintubation rate and pneumonia in postsurgical patients, and a reduction in ICU stay when NIV was used as weaning strategy. ${ }^{21}$ Authors of this meta-analysis concluded that a reduction in reintubation reduced the incidence of ventilator- associated pneumonia.

Routine use of NIV in postextubation period has been criticized because NIV may delay the intubation and delay in intubation is a risk factor for poor outcome. Esteban et al. ${ }^{11}$ reported that the interval between the onset of respiratory failure and reintubation was significantly longer in patients who received NIV and they also found that ICU mortality appeared to be higher in NIV group which may have contributed to delaying of intubation. NIV failure has also been identified as an independent risk factor ICU mortality in patients with acute respiratory failure. ${ }^{22}$ 
NIV in Postextubation Respiratory Failure

Table 2A: Quality of evidences as judged by GRADE methodology: Summary of findings

Noninvasive ventilation compared to standard oxygen therapy for after extubation

Patient or population: after extubation

Setting:

Intervention: Noninvasive ventilation

Comparison: standard oxygen therapy

\begin{tabular}{|c|c|c|c|c|c|c|}
\hline \multirow{2}{*}{$\begin{array}{l}\text { Outcome } \\
\text { No. of participants (studies) }\end{array}$} & \multirow{2}{*}{$\begin{array}{l}\text { Relative effect } \\
(95 \% \mathrm{Cl})^{*}\end{array}$} & \multicolumn{3}{|c|}{ Anticipated absolute effects (95\% Cl) } & \multirow[b]{2}{*}{ Certainty } & \multirow[b]{2}{*}{ What happens } \\
\hline & & & & Difference & & \\
\hline $\begin{array}{l}\text { Mortality at longest follow-up } \\
\text { No. of participants: } 1393 \text { (9 RCTs) }\end{array}$ & OR $0.84(0.50-42)$ & $14.8 \%$ & $\begin{array}{l}12.7 \% \text { (8.0 to } \\
19.8)\end{array}$ & $\begin{array}{l}2.1 \% \text { fewer ( } 6.8 \\
\text { fewer to } 5 \text { more) }\end{array}$ & $\begin{array}{l}\oplus \oplus O \bigcirc \\
L^{\prime} O W^{a}, b, c\end{array}$ & \\
\hline $\begin{array}{l}\text { Rate of reintubation } \\
\text { No. of participants: } 1525 \\
\text { (11 RCTs) }\end{array}$ & $\begin{array}{l}\text { OR } 0.75 \\
(0.51-1.09)\end{array}$ & $25.4 \%$ & $\begin{array}{l}20.4 \% \\
(14.8 \text { to } 27.1)\end{array}$ & $\begin{array}{l}5.1 \% \text { fewer } \\
(10.6 \text { fewer to } \\
1.7 \text { more) }\end{array}$ & $\begin{array}{l}\oplus \oplus O \bigcirc \\
L^{\prime} O W^{a}, b, c\end{array}$ & \\
\hline $\begin{array}{l}\text { Length of hospital stay } \\
\text { No. of participants: } 389 \text { ( } 4 \text { RCTs) }\end{array}$ & & & & $\begin{array}{l}\text { SMD } 0.07 \text { SD } \\
\text { higher (0.13 } \\
\text { lower to } 0.27 \\
\text { higher) }\end{array}$ & $\begin{array}{l}\oplus \oplus \bigcirc \bigcirc \\
\mathrm{LOW}^{\mathrm{a}, \mathrm{b}, \mathrm{c}}\end{array}$ & \\
\hline $\begin{array}{l}\text { Length of ICU stay } \\
\text { No. of participants: } 890 \text { (7 RCTs) }\end{array}$ & & $\begin{array}{l}\text { The mean } \\
\text { length of } \\
\text { ICU stay } \\
\text { was } 0\end{array}$ & & $\begin{array}{l}\text { MD } 0.46 \text { higher } \\
\text { ( } 0.43 \text { lower to } \\
1.36 \text { higher) }\end{array}$ & $\begin{array}{l}\oplus \oplus O \bigcirc \\
L^{\prime} O W^{a}, b, c\end{array}$ & \\
\hline
\end{tabular}

*The risk in the intervention group (and its $95 \%$ confidence interval) is based on the assumed risk in the comparison group and the relative effect of the intervention (and its 95\% Cl)

$\mathrm{Cl}$, confidence interval; $\mathrm{OR}$, odds ratio; SMD, standardised mean difference; $\mathrm{MD}$, mean difference

\section{GRADE Working Group grades of evidence}

High certainty: We are very confident that the true effect lies close to that of the estimate of the effect

Moderate certainty: We are moderately confident in the effect estimate: The true effect is likely to be close to the estimate of the effect, but there is a possibility that it is substantially different

Low certainty: Our confidence in the effect estimate is limited: The true effect may be substantially different from the estimate of the effect

Very low certainty: We have very little confidence in the effect estimate: The true effect is likely to be substantially different from the estimate of effect

\section{Explanations}

${ }^{\text {aNNonblinded }}$

${ }^{b}$ Use of NIV in standard therapy

'Therapeutic versus prophylactic use

On the contrary, NIV has been found to provide a benefit in terms of mortality and intubation rate in acute respiratory failure patients when compared to invasive mechanical ventilation or standard oxygen therapy. ${ }^{21}$ In our meta-analysis we have found benefit of NIV in terms of reintubation and mortality only in patients with COPD or chronic respiratory diseases, but not in other settings and it is well established that COPD patients are at high risk of extubation failure. A recent Cochrane database systematic review ${ }^{4}$ reported that use of NIV in the management of acute hypercapnic respiratory failure in COPD patients decreased mortality by $46 \%$ and need for intubation by $65 \%$. The quality of the evidence reported by the authors was 'moderate'. The official European Respiratory Society (ERS)/American Thoracic Society (ATS) guidelines also recommends use of NIV in these settings. ${ }^{23}$ However, in our univariate meta-regression analysis, we did not find any significant contribution of risk of reintubation in standard therapy group patients towards the ultimate effect of NIV on reintubation.

It is worth mentioning that most of the trials included in this meta-analysis used NIV as a rescue therapy in patients who received standard oxygen therapy also; hence magnitude of actual benefit from NIV may be higher than what is reported in the individual trials. In the RCT by Vargas et al., ${ }^{18}$ it was reported that incidence of respiratory failure was lower in patients who received NIV after extubation, but not the rate of reintubation or 90-day mortality. As the patients in standard oxygen therapy group also received NIV as rescue therapy, NIV might have some role in preventing re-intubation. Practice guidelines of American College of Chest Physicians (ACCP)/American Thoracic Society (ATS) recommends that NIV should be used after extubation in patients who are risk of extubation failure. ${ }^{24}$ We believe that this may be the single most important reason behind the lack of benefit from NIV in our meta-analysis.

A previous meta-analysis of 13 RCTs published in 2017 also evaluated role of NIV in post-extubation respiratory failure. The authors of this meta-analysis reported a significant reduction in rate of reintubation and mortality benefit in patients who received prophylactic NIV. ${ }^{25}$ However, our meta-analysis different from this one, as we have included patients who received post-operative mechanical ventilation and no subgroup analysis including patients with chronic respiratory disorders was reported. 
NIV in Postextubation Respiratory Failure

Table 3: Quality of evidences as judged by GRADE methodology when NIV is used as preventive strategy: Summary of findings Noninvasive ventilation compared to standard oxygen therapy for after extubation

Patient or population: after extubation

Setting:

Intervention: Noninvasive ventilation

Comparison: standard oxygen therapy

\begin{tabular}{|c|c|c|c|c|c|c|}
\hline \multirow{2}{*}{$\begin{array}{l}\text { Outcome } \\
\text { No. of participants (studies) }\end{array}$} & \multirow{2}{*}{$\begin{array}{l}\text { Relative effect } \\
(95 \% \mathrm{Cl})^{*}\end{array}$} & \multicolumn{3}{|c|}{ Anticipated absolute effects (95\% Cl) } & \multirow[b]{2}{*}{ Certainty } & \multirow[b]{2}{*}{ What happens } \\
\hline & & & & Difference & & \\
\hline $\begin{array}{l}\text { Mortality at longest follow-up } \\
\text { NIV as preventive strategy } \\
\text { No. of participants: } 1091 \text { (7 RCTs) }\end{array}$ & OR $0.68(0.38-1.23)$ & $13.7 \%$ & $\begin{array}{l}9.7 \% \\
(5.7-16.3)\end{array}$ & $\begin{array}{l}4.0 \% \text { fewer } \\
\text { (8 fewer to } 2.6 \\
\text { more) }\end{array}$ & $\begin{array}{l}\oplus \oplus \oplus \bigcirc \\
\text { Moderate }^{a, b}\end{array}$ & \\
\hline $\begin{array}{l}\text { Rate of reintubation } \\
\text { NIV as preventive strategy } \\
\text { No. of participant: } 1223 \text { ( } 9 \text { RCTs) }\end{array}$ & OR $0.65(0.40-1.06)$ & $18.6 \%$ & $\begin{array}{l}12.9 \% \\
(8.4-19.5)\end{array}$ & $\begin{array}{l}5.7 \% \text { Fewer } \\
(10.2 \text { fewer to } \\
0.9 \text { more })\end{array}$ & $\begin{array}{l}\oplus \oplus \oplus \bigcirc \\
\text { Moderate }^{a, b}\end{array}$ & \\
\hline $\begin{array}{l}\text { Length of ICU stay- } \\
\text { NIV as preventive strategy } \\
\text { No. of participants: } 588 \text { ( } 5 \text { RCTs) }\end{array}$ & & $\begin{array}{l}\text { The mean } \\
\text { length of } \\
\text { ICU stay - } \\
\text { NIV as } \\
\text { preventive } \\
\text { strategy } \\
\text { was } 0\end{array}$ & & $\begin{array}{l}\text { MD } 0.56 \text { Higher } \\
\text { ( } 0.38 \text { lower to } \\
1.49 \text { higher) }\end{array}$ & $\begin{array}{l}\oplus \oplus \oplus \bigcirc \\
\text { Moderate }^{b}\end{array}$ & \\
\hline
\end{tabular}

*The risk in the intervention group (and its $95 \%$ confidence interval) is based on the assumed risk in the comparison group and the relative effect of the intervention (and its 95\% Cl).

$\mathrm{Cl}$, confidence interval; $\mathrm{OR}$, odds ratio; SMD, standardised mean difference; $\mathrm{MD}$, mean difference

\section{GRADE Working Group grades of evidence}

High certainty: We are very confident that the true effect lies close to that of the estimate of the effect

Moderate certainty: We are moderately confident in the effect estimate: The true effect is likely to be close to the estimate of the effect, but there is a possibility that it is substantially different

Low certainty: Our confidence in the effect estimate is limited: The true effect may be substantially different from the estimate of the effect

Very low certainty: We have very little confidence in the effect estimate: The true effect is likely to be substantially different from the estimate of effect Explanations: a Non- blinded; ${ }^{b}$ Use of NIV in standard therapy; ${ }^{\text {T }}$ Therapeutic versus prophylactic use

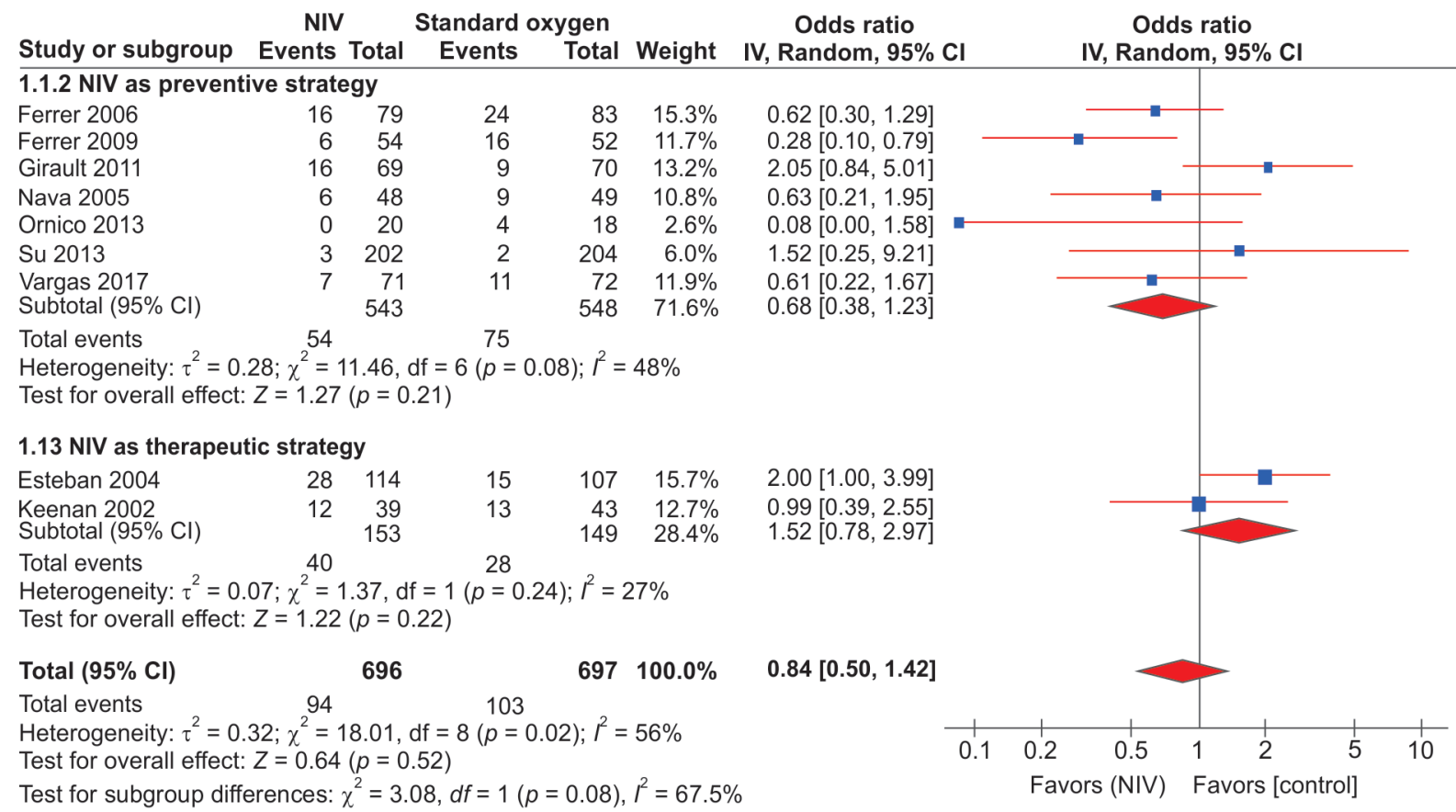

Fig. 3: Forest plot showing mortality at the longest available follow-up at individual study level and at pooled analysis level with the use of noninvasive ventilation and standard therapy. 


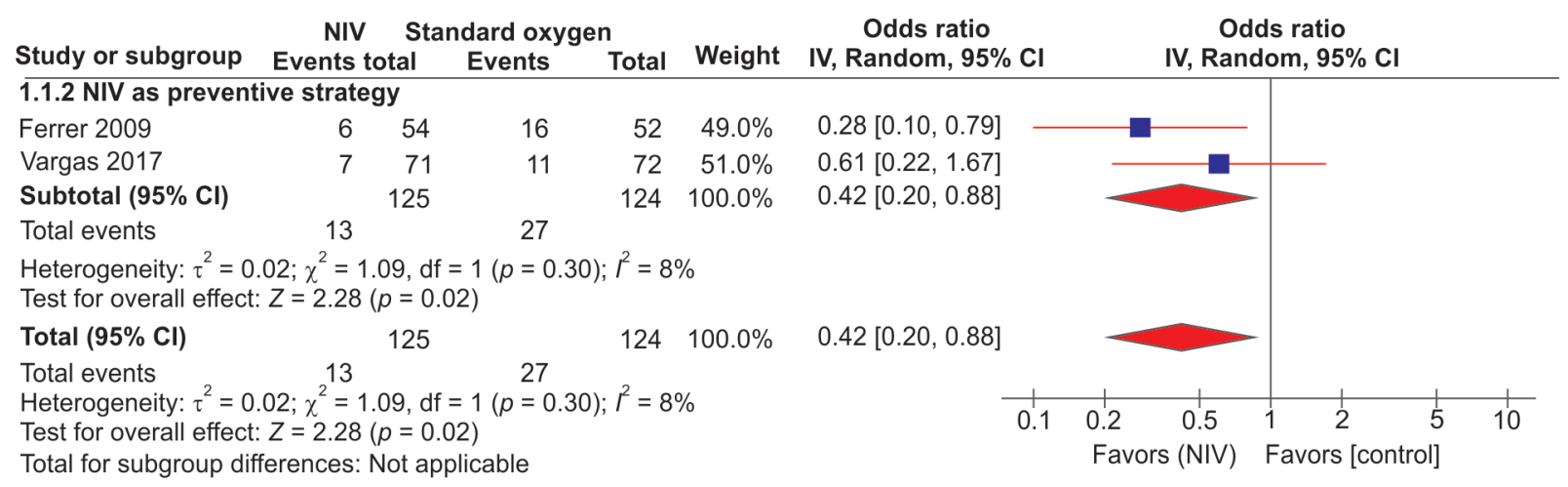

Fig. 4: Forest plot of odds ratio of mortality at longest available follow-up in patients with COPD or chronic lung diseases at individual study level and pooled analysis level

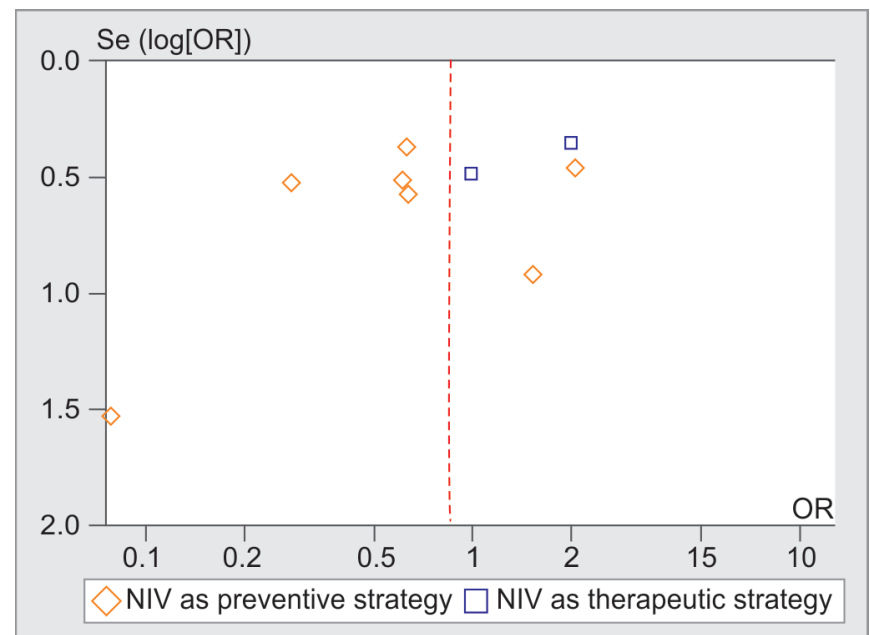

Fig. 5: Funnel plot for detection of publication bias in 'mortality at longest follow-up'

\section{Limitations}

Our meta-analysis has several limitations. We have found a significant amount of statistical heterogeneity in most of our analysis. Statistical heterogeneity is probably due to heterogeneous patients' population and also a varied NIV protocol across the studies also. Though some benefit of NIV has been found in COPD patients, number of patients in this sub-group analysis is small.

\section{Conclusion}

Postextubation NIV does not provide any benefit in terms of reintubation rate, mortality and length of stay when used either as a prophylactic or therapeutic strategy in patients with acute respiratory failure. Quality of evidences generated from this review was low to moderate. In patients with COPD or chronic lung diseases, rate of reintubation and mortality are decreased with the use of NIV.

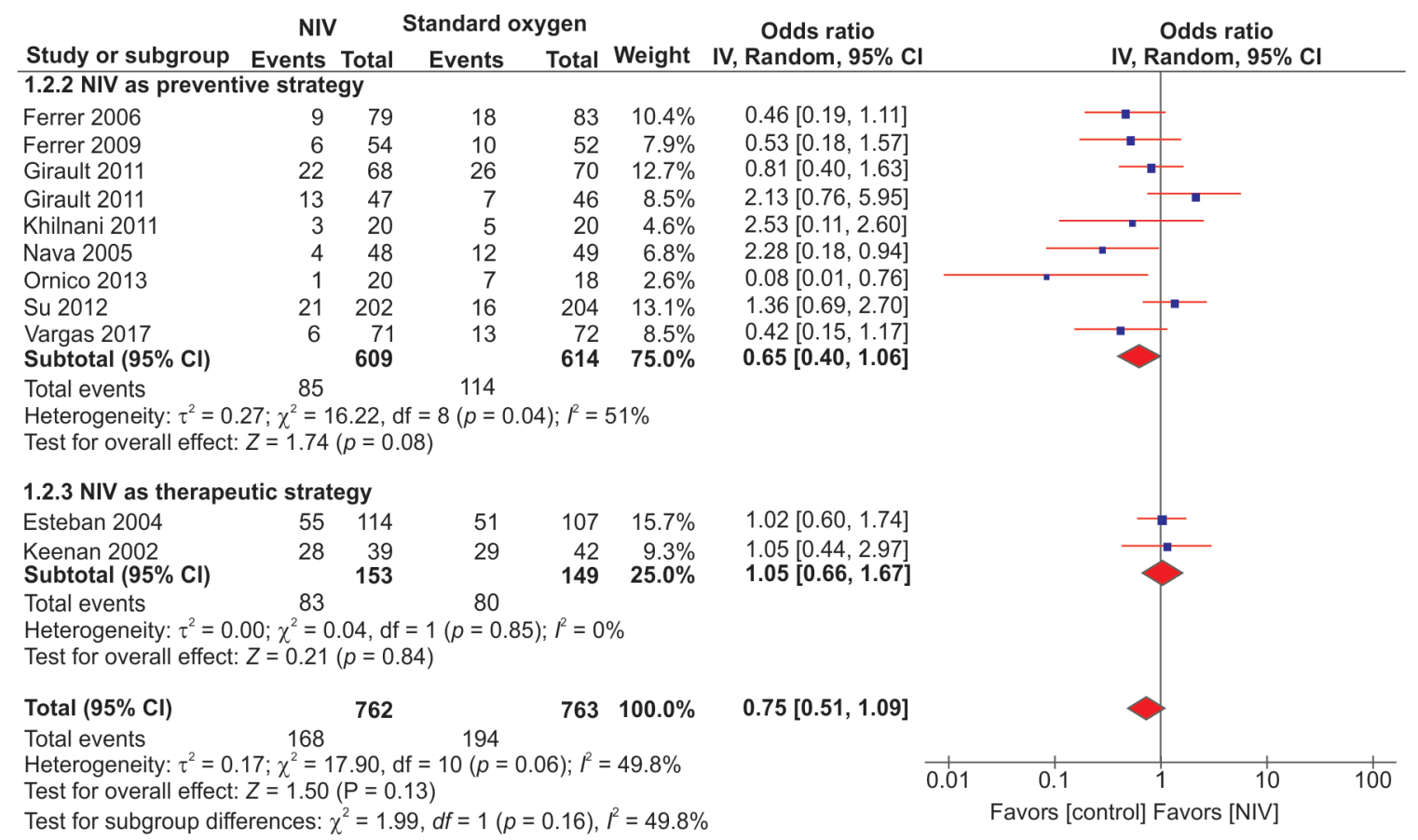

Fig. 6: Forest plot showing rate of reintubation at individual study level and at pooled analysis level with the use of noninvasive ventilation and standard therapy. 
NIV in Postextubation Respiratory Failure

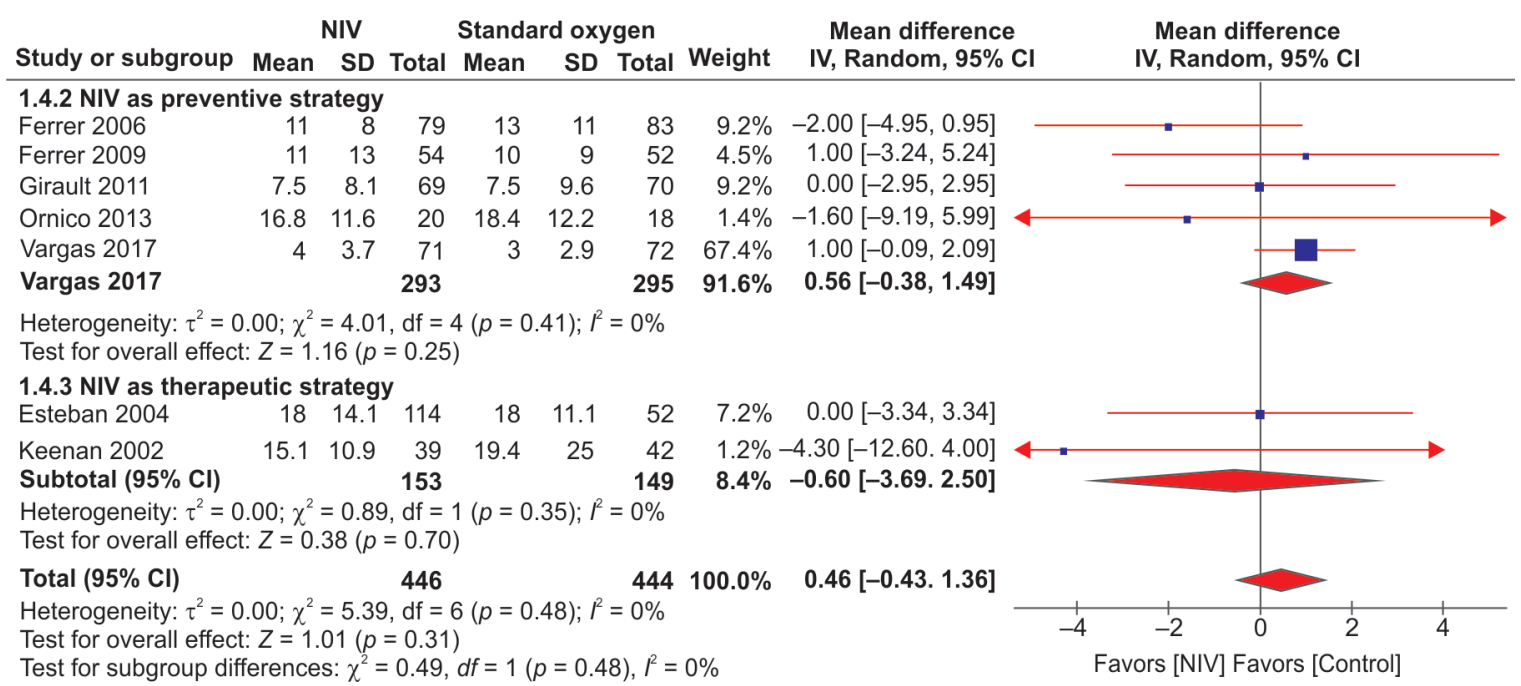

Fig. 7: Forest plot showing length of ICU stay at individual study level and at pooled analysis level with the use of noninvasive ventilation and standard therapy.

\section{References}

1. Colinas L, Canabal A, Hernández G. Reducing reintubation and postextubation respiratory failure: improving high-flow oxygen support performance. J Thorac Dis. 2016;8:E1429-E1431.

2. Demoule A, Chevret S, Carlucci A, Kouatchet A, Jaber S, Meziani F, et al.; oVNI Study Group; REVA Network (Research Network in Mechanical Ventilation). Changing use of noninvasive ventilation in critically ill patients: trends over 15 years in francophone countries. Intensive Care Med. 2016;42:82-92.

3. Schnell D, Timsit JF, Darmon M, Vesin A, Goldgran-Toledano D, Dumenil AS, et al. Noninvasive mechanical ventilation in acute respiratory failure: trends in use and outcomes. Intensive Care Med. 2014;40:582-591.

4. Osadnik CR, Tee VS, Carson-Chahhoud KV, Picot J, Wedzicha JA, Smith BJ. Non-invasive ventilation for the management of acute hypercapnic respiratory failure due to exacerbation of chronic obstructive pulmonary disease. Cochrane Database Syst Rev. 2017;7:CD004104.

5. Lin C, Yu H, Fan H, Li Z. The efficacy of noninvasive ventilation in managing postextubation respiratory failure: a meta-analysis. Heart Lung. 2014;43:99-104.

6. Vargas F, Clavel M, Sanchez-Verlan P, Garnier S, Boyer A, Bui HN. Intermittent noninvasive ventilation after extubation in patients with chronic respiratory disorders: a multicenter randomized controlled trial (VHYPER). Intensive Care Med. 2017;43:1626-1636.

7. Liberati A, Altman DG, Tetzlaff J, Mulrow C, Gøtzsche PC, loannidis JP. The PRISMA statement for reporting systematic reviews and meta-analyses of studies that evaluate health care interventions: explanation and elaboration. PLoS Med. 2009;6:e1000100.

8. Hozo SP, Djulbegovic B, Hozo I. Estimating the mean and variance from the median, range, and the size of a sample. BMC Med Res Methodol 2005;5:13.

9. Jiang JS, Kao SJ, Wang SN. Effect of early application of biphasic positive airway pressure on the outcome of extubation in ventilator weaning. Respirology. 1999;4:161-165.

10. Keenan SP, Powers C, McCormack DG, Block G. Noninvasive positivepressure ventilation for postextubation respiratory distress: a randomized controlled trial. JAMA. 2002;287:3238-3244.

11. Esteban A, Frutos-Vivar F, Ferguson ND, Arabi Y, Apezteguía $C$, González M. Noninvasive positive-pressure ventilation for respiratory failure after extubation. N Engl J Med. 2004;350:2452-2460.
12. Nava S, Gregoretti C, Fanfulla F, Squadron E, Fatty M, Carlucci A. Noninvasive ventilation to prevent respiratory failure after extubation in high-risk patients. Crit Care Med. 2005;33:2465-2470.

13. Ferrer M, Valencia M, Nicolas JM, Bernadich O, Badia JR, Torres A. Early noninvasive ventilation averts extubation failure in patients at risk: $a$ randomized trial. Am J Respir Crit Care Med. 2006;173:164-170.

14. Ferrer M, Sellarés J, Valencia M, Carrillo A, Gonzalez G, Badia JR. Noninvasive ventilation after extubation in hypercapnic patients with chronic respiratory disorders: randomised controlled trial. Lancet. 2009;374:1082-1088.

15. Khilnani GC, Galle AD, Hadda V, Sharma SK. Non-invasive ventilation after extubation in patients with chronic obstructive airways disease: a randomised controlled trial. Anaesth Intensive Care. 2011;39:217-223.

16. Su CL, Chiang LL, Yang SH, Lin HI, Cheng KC, Huang YC. Preventive use of noninvasive ventilation after extubation: a prospective, multicenter randomized controlled trial. Respir Care. 2012;57:204-210.

17. Ornico SR, Lobo SM, Sanches HS, Deberaldini M, Tófoli LT, Vidal AM et al. Noninvasive ventilation immediately after extubation improves weaning outcome after acute respiratory failure: a randomized controlled trial. Crit Care. 2013;17:R39.

18. Vargas F, Clavel M, Sanchez-Verlan P, Garnier S, Boyer A, Bui HN et al. Intermittent noninvasive ventilation after extubation in patients with chronic respiratory disorders: a multicenter randomized controlled trial (VHYPER). Intensive Care Med. 2017;43:1626-1636.

19. Frutos-Vivar F, Esteban A, Apezteguia C, González M, Arabi Y, Restrepo MI. Outcome of reintubated patients after scheduled extubation. J Crit Care. 2011;26:502-509.

20. Kondo Y, Kumasawa J, Kawaguchi A, Seo R, Nango E, Hashimoto S. Effects of non-invasive ventilation in patients with acute respiratory failure excluding post-extubation respiratory failure, cardiogenic pulmonary edema and exacerbation of COPD: a systematic review and meta-analysis. J Anesth. 2017;31:714-725.

21. Glossop AJ, Shephard N, Bryden DC, Mills GH. Non-invasive ventilation for weaning, avoiding reintubation after extubation and in the postoperative period: a meta-analysis. Br J Anaesth. 2012;109:305-314. Erratum in: Br J Anaesth. 2013;110:164.

22. Demoule A, Girou E, Richard JC, Taille S, Brochard L. Benefits and risks of success or failure of noninvasive ventilation. Intensive Care Med 2006;32:1756-1765. 
23. Rochwerg B, Brochard L, Elliott MW, Hess D, Hill NS, Nava S et al. Members of the Task Force. Official ERS/ATS clinical practice guidelines: noninvasive ventilation for acute respiratory failure. Eur Respir J. 2017;50.pii: 1602426.

24. Ouellette DR, Patel S, Girard TD, Morris PE, Schmidt GA, Truwit JD, et al. Liberation From Mechanical Ventilation in Critically III Adults: An Official American College of Chest Physicians/American Thoracic Society Clinical Practice Guideline: Inspiratory Pressure Augmentation
During Spontaneous Breathing Trials, Protocols Minimizing Sedation, and Noninvasive Ventilation Immediately After Extubation. Chest. 2017;151:166-180.

25. Krishna B, Sampath S, Moran JL. The role of non-invasive positive pressure ventilation in post-extubation respiratory failure: An evaluation using meta-analytic techniques. Indian J Crit Care Med. 2013;17:253-261. 